\title{
STUDIES OF THE GLOW DISCHARGE REACTIONS OF METHANOL AND ETHANOL
}

The effects of electric discharges on various organic compounds have been subjected to extensive investigations $\left[{ }^{1-3}\right]$. The decomposition of various hydrocarbons in glow discharge has been shown to be independent of bonding in the parent molecules as well as of the reaction conditions $\left[{ }^{4-6}\right]$. The effect of various functional groups on the chemical reactions under non-equilibrium plasma conditions is of interest, but no systematic study has been reported for any functional group, except for the investigations of Liu and Wightman $\left[{ }^{7}\right]$ and Hiraki $\left[{ }^{8}\right]$, in which the effect of the functional groups containing oxygen on the reactions of organic compounds, such as alcohols, ethers and ketones in the electric discharge has been investigated.

Liu and Wightman $\left[{ }^{7}\right]$ have found that in a microwave discharge alcohols, ethers and acetone decompose, and both gaseous products and polymeric film are formed.

Hiraki $\left.{ }^{8}\right]$ has found that the main products in the reaction of 2-propanol in the electric discharge were acetaldehyde, acetone, higher alcohols and hydrocarbons $\left(\mathrm{C}_{1}-\mathrm{C}_{4}\right)$; however, the distribution of the products varied with the reaction conditions. The action of the electric discharge on 2-propanol gave conversion from on 0.21 to 5.68 per cent.

In the present investigation the authors wish to report some observation on the chemical behaviour of methanol and ethanol in glow discharge plasma, at different power levels.

\section{Experimental}

Methanol and ethanol were made absolute and purified by column distillation. All the runs were carried out in a flow system using helium as dilutant. The $13.56 \mathrm{MHz}$ electric discharge was carried out in Pyrex tubing. The radio frequence energy was coupled by induction to the plasma. The capacity of the discharge zone was approximately $10 \mathrm{ml}$. The experimental arrangement is shown in Figure.

The reaction products passing through the discharge zone were separated and collected into condensers in liquid nitrogen. In the condenser containing activated charcoal methane, ethane, ethylene and acetylene were collected. Ail the experiments were carried out at pressure 


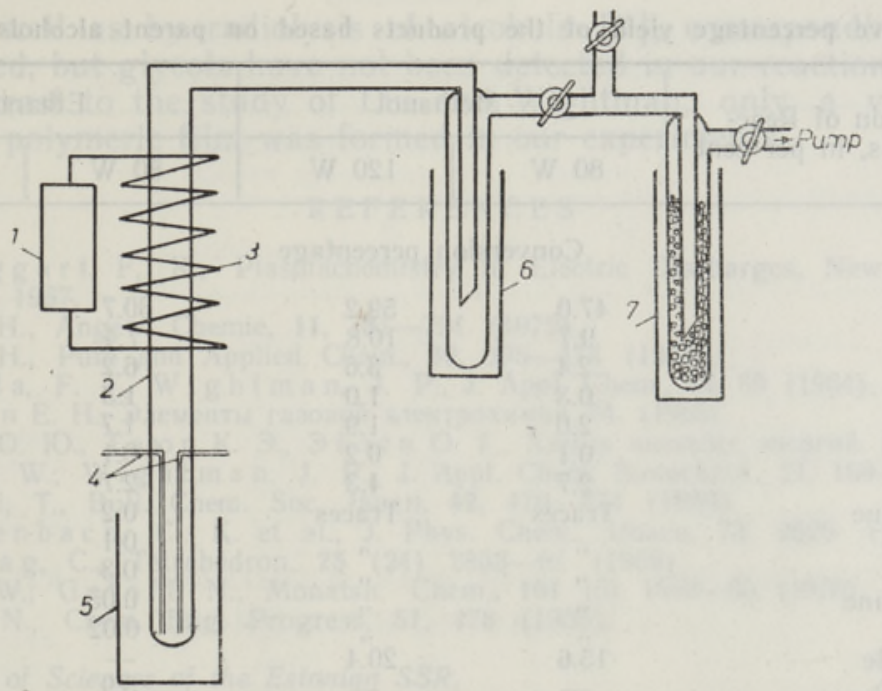

Scheme of the apparatus of plasmachemical reactions. 1 - HF generator, 2 - reaction tube, 3 - inductor, 4 - inlet tubes of alcohol and $\mathrm{He}, 5$ - thermostat, 6 trap for liquid products, 7 - trap with charcoal for gaseous products.

of 3 Torr and at two different power levels, 80 and $120 \mathrm{~W}$. The flow rates of the carrier gas and correspondent alcohol were $40 \mathrm{ml}$ and $0.1 \mathrm{ml}$ per minute, respectively. The reaction products were identified by comparing their retention times with those of authentic samples in gas chromatography (PEG=6000 at $60^{\circ}$ and Polysorb-1 at 25, 60 and $120^{\circ} \mathrm{C}$ ).

Besides the above-mentioned products formed, carbon monoxide, carbon dioxide, hydrogen and water have been detected.

\section{Results and discussion}

The composition of the identified reaction products of methanol and ethanol is presented in Table. The percentage composition of the compounds shown in Table is the average of the two experiments. The main products formed in these reactions were hydrocarbons and compounds containing oxygen. No difference in the qualitative composition between the reaction products of alcohol at power levels 80 and $120 \mathrm{~W}$ was found, only the conversion percentage was effected by the power output.

The action of glow discharge plasma on methanol and ethanol produces mainly identical hydrocarbons with significantly different distribution. The main hydrocarbons formed in these plasma reactions were methane, ethane, ethylene and acetylene. The amounts of hydrocarbons $\mathrm{C}_{3}-\mathrm{C}_{5}$ in case of methanol and ethanol were not very significant. Comparison of the present results with those of Liu and Wightman $\left[{ }^{7}\right]$ is interesting. Thus, the decomposition of the parent compounds in the microwave discharge $\left[{ }^{7}\right]$ approached 100 per cent for the seven oxygencontaining compounds, whereas hydrogen and carbon monoxide were the main $(90 \%)$ decomposition products. Gases observed in the microwave discharge of alcohols are similar to those predicted for high temperature reactions $\left[{ }^{9}\right]$. 
The relative percentage yield of the products based on parent alcohols consumed

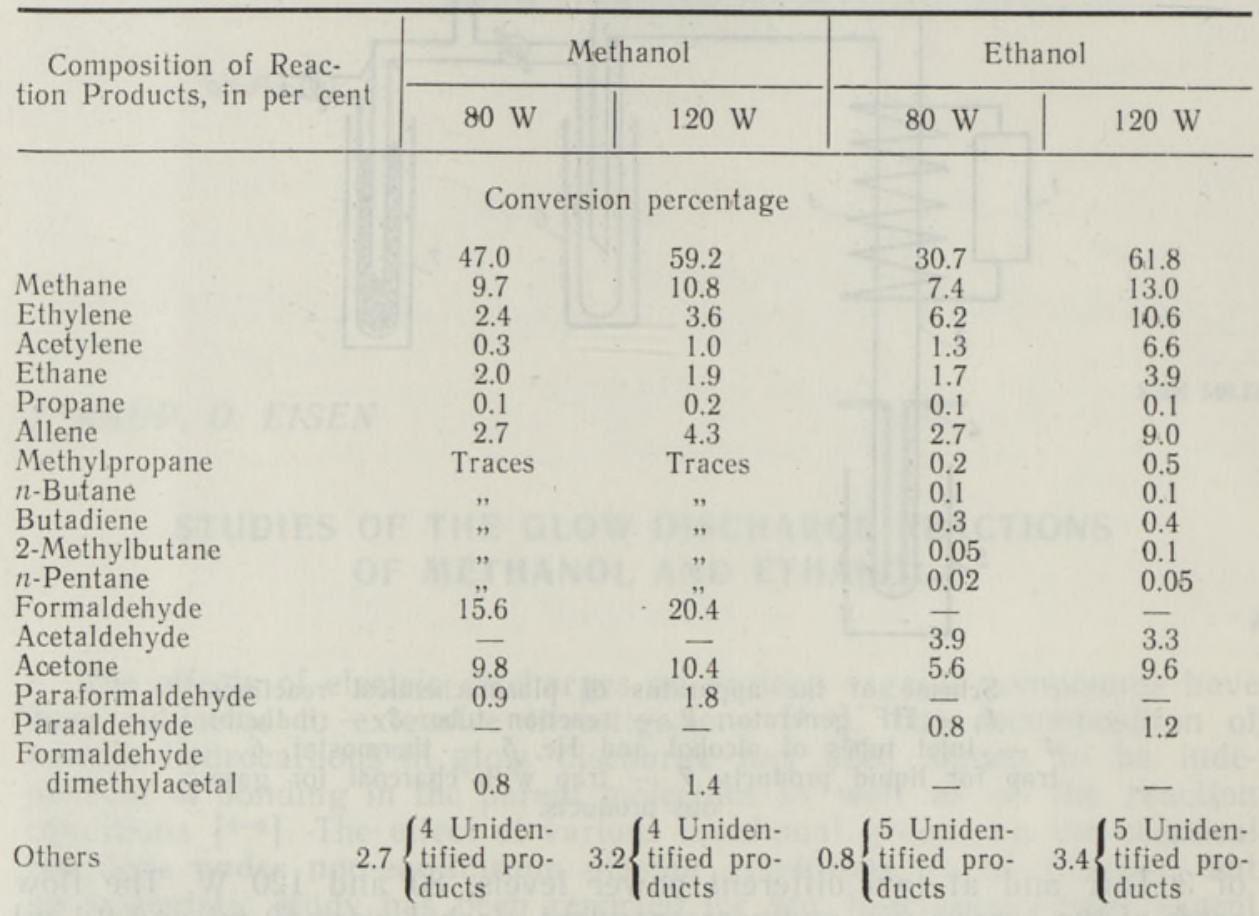

The present study was not intended to elucidate the reaction mechanism occurring in the radiofrequency discharge of alcohols; however, some aspects of the mechanism of the formation of reactions products may be inferred. It has been found $\left[{ }^{1-3}\right]$ that the action of the electric discharge on a chemical compound seems to be the electronic excitation of molecules. The excited molecules may decompose or isomerize either to stable compounds or to reactive intermediates which are precursors of the final products. It can be assumed that methane and ethane may be formed from methyl radical or ion (e. g., $\mathrm{CH}_{3}$ or $\mathrm{CH}_{3}^{+}$). In case of methanol the formation of hydrocarbons $\mathrm{C}_{2}$ (ethane, ethylene and acetylene) and higher ones probably involves a recombination of species such as $\mathrm{CH}_{3}, \mathrm{CH}_{2}$ and $\mathrm{CH}$ which have been produced by collision between high-energy electrons and parent molecules on radicals and ions. Comparatively higher yields of hydrocarbons $\mathrm{C}_{2}$ have been formed of ethanol than in the case of methanol, but the similar yields of methane in case of both alcohols permit to assume that ethylene, ethane and acetylene may be formed from alcohol in the electric discharge in two ways, either from the species $\mathrm{CH}_{3}, \mathrm{CH}_{2}, \mathrm{CH}$, which occurs mainly in case of methanol, or by dehydrogenation and dehydration of alcohol without breaking the $\mathrm{C}-\mathrm{C}$ skeleton. The latter mechanism of the formation of hydrocarbons $\mathrm{C}_{2}$ probably takes place in case of ethanol.

Much acetone and aldehyde has been formed in these reactions. This is similar to the case of 2-propanol reaction in electric discharge [ $\left.{ }^{8}\right]$. It can be assumed that aldehydes have been formed by the dehydrogenation of corresponding alcohols by the removal of a pair of hydrogen atoms. However, it seems that acetone has been formed from the methyl and methoxy radicals. It has been reported by Sonntag $\left[{ }^{10}\right]$, Zich and Getoff [11] and Bach [12] that by photolysis of methanol 
$\left[{ }^{10,11}\right]$ as well as by radiolysis of alcohols $\left[{ }^{12}\right]$, corresponding glycols were formed, but glycols have not been detected in our reaction products.

In contrast to the study of Liu and Wightman, only a very small amount of polymeric film was formed in our experiments.

\section{REFERENCES}

1. M c T a g g a rt, F. K., Plasmachemistry in Electric Discharges, New York Elsevier, 1967.

2. Suhr, H., Angew. Chemie, 11, 781-791 (1972).

3. Suhr, H., Pure and Applied Chem., 39, 395-414 (1974).

4. V a stola, F. J., W i g h t m a n, J. P., J. Appl. Chem., 14, 69 (1964).

5. Е ре м и н Е. Н., Элементы газовой электрохимии, М. (1968).

6. К а уп Ю. Ю., Т а юр К. Э., Э й зен О. Г., Химия высоких энергий, № 1 (1977).

7. Li u, S. W., W ight m a n, J. P., J. Appl. Chem. Biotechnol., 21, 168-172 (1971).

8. Hiraki, T., Bull. Chem. Soc. Japan, 42, 470-474 (1969).

9. We if fe n bach, C. K. et al., J. Phys. Chem., Ithaca, 73, 2526 (1969).

10. Sonntag, C., Tetrahedron, 25 (24) 2853-61 (1969).

11. Z i ch, W., G et of f, N., Monatsh. Chem., 101 (5) 1583-90 (1970).

12. B a c h, N., Chem. Eng. Progress, 51, 478 (1955).

Academy of Sciences of the Estonian SSR, Institute of Chemistry

\section{METANOOLI JA ETANOOLI KEEMILISEST MUUNDUMISEST HUUMLAHENDUSPLASMAS}

Uuriti metanooli ja etanooliga kõrgsageduslikus $(13,56 \mathrm{MHz})$ huumlahendusplasmas toimuvaid reaktsioone.

Reaktsioonid teostati läbivoolusüsteemiga aparatuuris, kandegaasina kasutati heeliumi. Reaktsiooniproduktid määrati gaasikromatograafiliselt. Võimsusel $120 \mathrm{~W}$ oli metanooli ja etanooli muundumisprotsent vastavalt 59,8 ja 61,8 .

Alkoholidest tekivad huumlahenduses süsivesinikud ja hapnikuühendid.

Ю. КАУП, О. ЭНЗЕН

\section{ИССЛЕДОВАНИЯ ПРЕВРАЩЕНИИ МЕТИЛОВОГО И ЭТИЛОВОГО СПИРТОВ В ТЛЕЮЩЕМ РАЗРЯДЕ}

Реакции превращения метилового и этилового спиртов в плазме тлеющего разряда (13,56 Мгц) проводили в проточной системе под давлением 3 м. рт. ст. Газом-носителем служил гелий. Состав продуктов реакции определяли методом газо-жидкостной хроматографин. Степень превращения метилового и этилового спиртов при мощности разряда 80 вт составляла соответственно 47 и $30,7 \%$, а при мощности разряда 120 вт 59,2 и $61,8 \%$. Метиловый и этиловый спирты превращались как в углеводороды, в том числе в метан, этан, этилен, ацетилен, так и в альдегиды - ацетон и ацеталь. Предположено, что углеводороды $\mathrm{C}_{2}$ образуются в тлеющем разряде как из частиц СН, так и в результате дегидрирования и дегидроксилирования спирта. 